Click www.researchjournal.co.in/online/subdetail.html to purchase.

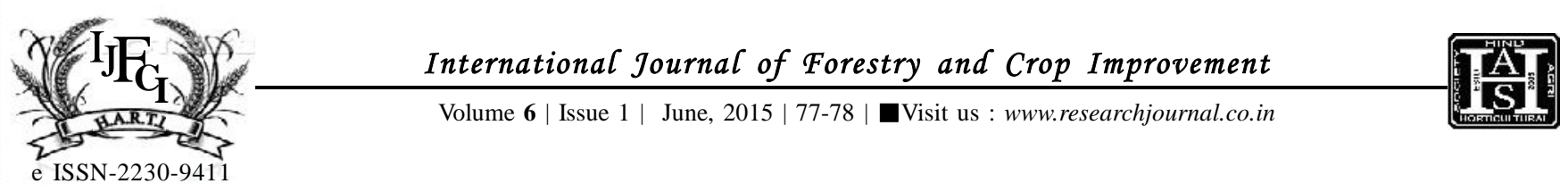

A ReVIEW

DOI: $10.15740 / \mathrm{HAS} / \mathrm{IJFCI} / 6.1 / 77-78$

\title{
Chickpea and weed management
}

\author{
PRITAM OMPRAKASH BHUTADA
}

KEY WORDS : Chickpea, Weed management

HOW TO CITE THIS ARTICLE : Bhutada, Pritam Omprakash (2015). Chickpea and weed management. Internat. J. Forestry \& Crop Improv., 6 (1) : 77-78.

Article Chronical : Received : 06.02.2015; Accepted : 07.05.2015

\section{INTRODUCTION}

As chickpea is important pulse crop among the all pulses. Chickpea have highest area and production in India. Pulses have important property to improve soil fertility, so they acquire dominant place in cropping system and rich in protein, mineral and vitamin play vital role in human diet.

As per ICMD recommended dose of pulses per capita per day is $75 \mathrm{~g}$ but only $36 \mathrm{~g}$ is available for that increase production weed is major problem. Once of major obstacles in growing chickpea successfully in their poor ability to compete with weeds. Crop losses of 90 per cent are possible situations (Knights, 1991) and the lack of registered post emergence herbicides for broadleaf weeds reduces the options for weed management (Wright et al., 1995). Chickpea can grow in wide range of soil type it prefers the medium to clays (Knights, 1991). But excepting these there are number of difficulties associate with growing chickpea in India.

ADDRESS OF THE CORRESPONDENCE

PRITAM OMPRAKASH BHUTADA, Space Applications Centre, Indian Space Research Organisation, AHMEDABAD (GUJARAT) INDIA

Email: pritambhutada1@gmail.com
Current weed control status and future scope :

Weed emergence with the Rabi sown chickpea crop creates a severe competition unless controlled timely and effectively. Inter-row cultivation is not sufficient and inter-row hand weeding is necessary under most conditions. There is, therefore, an urgent need to move from the costly manual mechanical weed control to chemical weed control (Marwat et al., 2003).

Methods used to control weeds in various crops include manual, mechanical, cultural including crop rotations, crop competition, biological and chemical. The first two methods are common in the less developed farming systems while the last is dominant in the industrial Imazethpyr \{2-[4,5-dihydro-4-methyl-4-(1-methylethyl)5-oxo-1H-imidazol-2-yl]5-ethyl-3-pyridinecarboxylic acid $\}$ is an imidazolinone compound used as a selective herbicide to control most annual grasses and certain broadleaf weeds. This herbicide is applied as pre-plant incorporated, pre-emergence and early post emergence for control of annual and perennial grass and broad-leaf weeds in chickpea and other legume fields (Peterson et al., 2001).

Bhutada and Bhale, 2013 observed that Pendimethaline $1 \mathrm{~kg} \mathrm{ha}^{-1}+1 \mathrm{H}$ at $40 \mathrm{DAS}$ recorded highest yield in chemical treatment which is comparable with cultural weed control treatment $2 \mathrm{H}$ at 15 and 40 DAS + 